\title{
Transformation and Quality of Social Services in Slovakia: Implications of Social Role Valorisation Concept
}

\author{
Kvetoslava Repkova \\ The Institute for Labour and Family Research, Bratislava, Slovakia
}

Email address:

kvetoslava.repkova@ivpr.gov.sk

To cite this article:

Kvetoslava Repkova. Transformation and Quality of Social Services in Slovakia: Implications of Social Role Valorisation Concept. Social Sciences. Vol. 7, No. 5, 2018, pp. 203-210. doi: 10.11648/j.ss.20180705.11

Received: August 10, 2018; Accepted: August 23, 2018; Published: September 28, 2018

\begin{abstract}
The topic of the quality of social services has been officially institutionalised in Slovakia since 2009 as part of the historically first separate act on social services, as well as a part of the general efforts focused on the transformation of social services. Although the quality system is primarily a policy concept, numerous parallels with the concept of the social role valorisation can be observed. The aim of the study is to present selected aspects of recent developments in the implementation of the new quality system in Slovakia based on the research conducted in 2016. These questions were addressed: According to the providers, is more profound transformation of social services in Slovakia necessary? If yes, what should the transformation relate to? What is the providers' opinion on the importance of the quality system as part of transformation of social services? What changes do the providers expect in their organisations with regards to the implementation of the quality system? As the research findings shown, the absolute majority of respondents (social service providers) considered the transformation of social services for necessary, while adoption of measures at several levels is necessary. Expectations of transformation changes at systemic level (e.g. financing of social services, stabile legislation, equal status of public and non-public providers), at organisational level, as well as the level of professional performance of social services were identified. The emphasis was put particularly on the need for systemic changes in social services, with considerably lower representation of expected changes at the organisational as well as professional levels. Respondents expressed high confidence in the quality of their own services, not being aware of any major reserves. In the discussion, the author appreciates the concept of the social role valorisation for interpreting and explanations of the obtained, sometimes contradictory, research results.
\end{abstract}

Keywords: Social Services, Transformation, Quality, Quality of Social Services, Social Role Valorisation Concept, Long-Term Care Services

\section{Introduction}

The topic of the quality of social services has been officially institutionalised in Slovakia since 2009 as part of the historically first separate act on social services (Act No. 448/2008 Coll. on Social Services, hereinafter referred to as „the Act "). [1] The need for implementation of the national system of quality of social services (hereinafter referred to as „the Q-System“) into the activities of social service providers was declared a political priority in several significant documents. In the past decade it has been strongly associated with the strategy of transformation and deinstitutionalisation of social services (2011) [2], and with the recent national action plan of transformation from institutional to community care (2016) [3]. It is declared a national priority of special interest in the document "National priorities of the development of social services in 2015-2020" (2014) [4]. In the light of the commitments arising from the Convention of the Rights of Persons with Disabilities [5], ratified by the Slovak Republic in 2010, transformation and quality of social services is interpreted as the fulfilment of human rights and freedom of social service users, the way to offer choices, support of self-determination and general quality of life, in combination with the commitments in terms of professional assurance and good quality environment for social service provision.

Although the Q-System is primarily a policy concept, based on the deeper exploration of its contents, numerous parallels with theoretical and interventional concept of the social role valorisation (hereinafter referred to as "the SRV") 
can be observed. The aim of the study is to present selected aspects of recent developments in the implementation of the Q-System in Slovakia, relying on research findings of the author interpreted through the SVR as an inspiration for science and research as well as teaching practice.

\section{Terminology}

For the purposes of the study it is useful to start with the definition of some basic concepts. Social services are individualised services delivered to individuals, families and communities during various unfavourable living and social conditions in order to restore or maintain their abilities to effectively deal with their social problems and to get integrated into society. [1, 6, 7]

Transformation of social services is a complex process of adjustment of system environment of social services (legislation, competences, financing, position in the system of people's social protection), improving the quality of functioning of social service organisations and ensuring their professional performance in accordance with human needs, social progress and social knowledge. [8] On the national level, transformation of social services is significantly associated with their deinstitutionalisation. [2]

Quality of social services may be defined in different ways: a) quality as an intrinsic characteristic of social services, individually and/or collectively perceived fairness of the services, but not subject to measurement; b) quality as a norm, subject to measurement, when the level of provided services is compared to the expected one, which functions as a norm; c) quality as an excellence, and as a permanent progress of both technical and relational aspects of provided social services. [9-10]

The Q-System can be operationalized as a set of structures and measures executed in two interacting levels. The first level represents commitments of social service providers to provide social services that conform to the criteria and standards set by law in four areas: a) the area of basic human rights and freedom protection, b) the area of procedures, c) the area of personal conditions, d) the area of operating conditions. The commitments of providers include the preparation of the necessary documentation (administrative and documentary quality aspect) as well as the practice performed in accordance with the documentation (conative aspect of quality). The second level of the Q-System relates to the role of the Ministry of Labour, Social Affairs and Family of the Slovak Republic (hereinafter referred to as "the ministry") of external evaluation of social service providers to fulfil the quality commitments according to 21 quality criteria and indicators set by law. [8]

The $S R V$ is a concept of social science, bringing the intervention dimension into the general role theory in order to adjust, establish, promote, maintain and defend valuable social roles for people [11], including those to whom the social services are delivered. Thus, the theory was developed as a concept of transaction of human relationships and human services [12].

\section{Parallels Between Q-System and SRV}

Several key parallels can be identified that legitimise the application of theoretical and interventional setup of the SRV for analysing the Q-System in the Slovak conditions, despite the fact that both systems were formulated in a fundamentally different time as well as social and policy context. The following parallels are described:

1. Historical context

As the residential services in 1970ies were developing for people with health (mainly mental) disabilities in Scandinavia and North America [12-13], leading to necessary changes, efforts to make necessary changes in residential social services for people with disabilities and elderly in Slovakia have been undergoing during the past two decades. [8-14]

2. Impact of services on service users

Common "wounds" of societally devalued people described by Susan Thomas and Wolf Wolfensberger (1999) [11] were comparable with those identified by experts on the national level (such as medical approach in social services, viewing users as objects, infantilization of users, loss of control over life, institutional practices, disruption of social relations). $[8,14,15,16]$

3. Nature of changes

The requirements for transformation of human services resulted from the effort to change devalued social positions and roles of their users based on the principle of social justice and access to the good things of life for the users. [17, 18, 19, 20] Similarly, the Q-System builds on the principles of social justice and human rights of the users, from which the whole intervention practice and its evaluation is derived. [8-14]

4. Intervention measures

Intervention measures focused on the valorisation of service users' social roles include social actions oriented at the promotion of their competencies and image. The way these services are provided and organised has a significant impact on building competencies and image of both users and providers. [11, 13, 19] In the Q-system, the building of the competencies and image of social service users is reflected primarily in the imperative of universal human dignity, combined with uniqueness of individuals, their skills and abilities; in commitments to promote social status of individuals, preservation of their identity and personal integrity in life; and in commitments to create a positive image of users and providers of social services. [1, 8, 14]

5. Quality evaluation and education of actors

External evaluation of the quality of human services was part of the SRV. The assessment tool PASS was originally developed for the purposes of the evaluation, since 2007 as "A Tool for Analysing Service Quality According to Social Role Valorisation Criteria. Rating Manual - PASSING”. [21] Within the assessment tool development, educational topics were identified for the human service providers in order to increase their professional awareness on the SRV principles. [11] At the same time, a proposal for the manual how to implement the quality of social services in practice was 
created in 2015 at the national level. [22] Moreover, a proposal for the manual on external evaluation of the quality of social services according to the criteria set by the law was elaborated in 2016. [23] The educational programme for future quality evaluators was subsequently drafted. [24] Starting 2019, all documents will be subject to validation and, if necessary, subsequent revision at the national level.

\section{Research}

In Slovakia, the specific character of transformation and implementation of the Q-System is a 10-year time interval between the period of obligation for the providers to follow the quality standards set by law (since 2009) and the period of starting official evaluation by the ministry (since 2019). This fact could have influenced the statements of the providers regarding the commitments in the area of social service quality, their expectations from the Q-System, and the significance attributed to necessary changes and commitments as well as their strategy to fulfil quality requirements. Since 2016, some attention has been focused on the research of the above-mentioned topics.

In preparation for the introduction of the quality evaluation system initially scheduled for the beginning of 2017, the research in the first half of 2016 to learn the opinions of social service providers on the need for transformation of social services and the importance of quality policy was carried out. A follow-up explanation model was applied [25] in the complex research project, what enabled to combine the initial investigation in a bigger sample of social service providers with the following qualitative investigation in order to provide a detailed explanation of the results from the primary phase. The methodological design and key findings from the first part of the research are described below and selected research findings will be further discussed in the SRV context.

\subsection{Methodology}

The aim of the research was to seek the views of different social service providers on the needs for transformation of social services including the significance attributed to the implementation of the Q-system according to the requirements set by the law. The key research question was formulated: What is the providers' perception of the importance of the Q-System for general transformation of social services? Partial research questions (hereinafter referred to as "PRQ") were defined, namely:

PRQ1: According to the providers, is more profound transformation of social services in Slovakia necessary? If yes, what should the transformation relate to?

PRQ2: What is the providers' opinion on the importance of the Q-System as part of transformation of social services?

PRQ3: What changes do the providers expect in their organisations with regards to the implementation of the QSystem?

The responses of the providers to the questions formulated above are considered an important indicator of how they understand new commitments in the quality of social services; internalisation of values on which the Q-System is built; and the preparedness to fulfil these values in practice. Such research has not been carried out in the preparatory process for the implementation of the Q-System in Slovakia until 2016.

For the purposes of the research, the T-Q questionnaire [8] consisting of the set of closed and open questions including basic identification data of the respondents (social service providers) was prepared. The responses to open questions were coded, subsequently categorised and quantitatively processed and interpreted together with the responses to closed questions. When preparing the questions, the author relied on theoretical as well as intervention implications of the SRV in order to identify the need for transformation of social services from the providers' perspective; to find out how the transformation expectations are structured in their reflection; if the expectations can be arranged into certain levels; and if yes, what is the definition of these levels in terms of their contents. A particular interest was to find out what potential do the providers see in the Q-system for the changes in their own organisation and practical work with the service users.

The questionnaire was administered electronically. For the purposes of administration, some cooperation with umbrella organisations of providers in Slovakia, who had targeted the providers to complete the questionnaire was developed. The research sample included 121 social service providers, of which $52 \%$ were non-public service providers and $48 \%$ were public providers. More than one half of the participants $(58 \%$ of the total sample) provided different sorts of social services, most often a combination of residential social services for care dependent persons with disabilities and/or elderly with services of crisis intervention. The sample was represented by providers from all regions in Slovakia.

\subsection{Main Research Findings}

\subsubsection{Main Research Findings Related to PRQ1}

The respondents were asked if more profound transformation of social services is necessary, and if yes, what should the transformation relate to. Out of 121 respondents, 111 (almost $92 \%$ of the total sample) considered the transformation of social services for necessary. A total of 225 responses was received to the open question what the transformation should relate to. These answers were coded and subsequently categorised into three arbitrary categories representing the levels of the necessary transformation changes in the respondents' expectations, particularly:

1. Transformational changes at the system level

This category was most often represented $(66 \%$ of all statements) and included all statements as they relate to the need for transformation of the relevant national legislation and regulations at different levels (national, regional, and local), recognition of general values and principles of social services towards ensuring human rights of their users, including the right to life in their natural family and community environment. Most reflected transformation 
domains within this category included the requirement for adjusting the social service funding, ensuring an equal status of public and non-public providers, unification of assessment procedures in social services, ensuring the accessibility and sustainability of social services, and their consistent directness linked to the needs of the targeted groups. The requirements for simplification of the Q-System including the registration procedures were also included in this category.

2. Transformational changes at the organisational level

This category was represented to a lesser extent in the statements of social service providers $(20 \%$ of all statements). The requirements for the adoption and implementation of the providers' quality policy according to the law, deinstitutionalisation oriented at humanisation of social services, the need for decreasing the size capacity of organisations, and requirements for environment adjustments as well balanced consideration of the needs and rights of both the users and providers of social services were also incorporated in this category.

\section{Transformational changes at the professional level}

This was the least represented category of requirements for transformational changes (almost 14\% of all statements) in the providers' views, although closely associated with the QSystem. The requirements included mainly the need to apply an individual approach of the providers' staff towards the users. This requires education of the staff along with sufficient personal capacities necessary to guarantee the professionalism in social service.

As is evident from the results, according to the majority of respondents, the adoption of measures at the level of the overall system of social services was at the core of all transformational changes, which form the basis for changes at lower levels - at the level of organisations and their staff directly associated with the Q-System. Such professional statements are illustrated by the following opinions:

"Addressing the quality or the superstructure of social services without any sufficient resources for basic standard services from the state and self-government is WRONG and non-logic!!!"

"With current 'low quality' financing of social services the quality will not be important; to keep the organisation running is what counts".

In the light of these statements the quality policy of providers and changes in social service provision are more or less considered as a superstructure to the primary need for consolidation of external conditions for social services. They indicate that without consolidation of social service financing from public resources and creation of stable legal conditions for normal operation of providers it is not possible or wellfounded to expect qualitative changes in their activities.

The statements which define a transformational change as the need for a change in the attitude towards social service users, and a change in the way of thinking of all actors involved belonged to significantly less represented statements. The fact that it is hard to achieve is illustrated by the following statements of the respondents:
"Provision of social services should be more professional...and the attitude towards the user is essential. The employees must realize that they are professionals, and therefore professional work is required".

"The most difficult task is to change the people's way of thinking - both clients and employees".

\subsubsection{Main Research Findings Related to PRQ2}

The diversity of statements on the transformation of social services has indicated that a deeper investigation of the respondents' opinions regarding the Q-system, as a part of the overall transformation of social services, is justified. We asked them whether they consider the Q-System as: a) a chance to sum up the existing situation and an excellent basis for transformation of their own organisation towards quality; b) a good idea, which is, however, hard to perform; c) an unnecessary administrative burden. Almost 53\% of respondents considered the Q-System as an excellent opportunity to sum up what they have achieved and to identify things that should be changed. Within the Q-System they mostly appreciated a challenge of strengthening an individual work with the users and their families, respecting human rights and freedom of users, de-stereotypisation of the approach towards the users and their mobilisation, using new and complex forms of interventions within the unified management and team work of professionals.

However, 39\% of respondents considered the Q-System in its nature as a good idea but hardly feasible. According to their opinion, the reasons for complicated feasibility included mainly unnecessary administrative tasks, a great number of quality indicators to be followed, and associated paper-based work, often detrimental for the work with people. Eight percent of the respondents considered these particular reasons as an unnecessary administrative burden in the QSystem that prevents the expected objective from being met.

\subsubsection{Main Research Findings Related to PRQ3}

As mentioned above, the Q-system was viewed by most of the respondents as a positive challenge for their work and organisation. Deeper understanding of what that really means was supported by further research. The respondents were asked if, based on the Q-system requirements, they felt that more fundamental changes within their organisations should be adopted so that their services were considered to be of high quality. According to more than $45 \%$ of respondents, no major changes were needed in their organisations in order to provide high quality services. Up to $32.5 \%$ of respondents stated that changes are necessary, but only minor amendments particularly in the area of barrier-free access, staff policy, elaboration of job standards (quality documentation), and additional financing of the services. Only one fifth of respondents (22\%) admitted the need for substantial changes at the organisational level, and changes in direct work performance. They highlighted the necessity for a change in the attitude towards the users through the empowerment of responsibility for their own life, the need for deinstitutionalisation and changes in attitudes of employees to their work obligations. Unlike respondents 
from the previous group who considered the quality management and elaboration of quality standards for the needs of the organisation, staff and remuneration policy, education and supervision as minor adjustments, the respondents from the second group had identified as major changes at the organisational level.

High confidence of most providers in the quality of their social services was empowered in the explicit question how they assess the quality of their own social services offered to their clients. According to almost all respondents (up to 95\% of the total sample) they provide services of high quality. Their positive response was mostly derived from informal expression of users' satisfaction and their families and ongoing demand for their services. Based on this finding it was not surprising that according to almost $70 \%$ respondents, the introduction of the Q-System in their organisation would not lead to a significant change in the provision of social services as they are of good quality regardless of new responsibilities set by the law. Only about $19 \%$ of respondents expect a positive impact of the Q-System in the future, particularly in the area of person-centred care, application of human rights and freedom in all fields, better cooperation of key actors in social services, high quality management, and unified procedures for expert teams in better work environment.

\section{Discussion}

The survey analysed the opinions of selected providers on the necessity of social services' transformation, during the period of gradual implementation of the Q-System in the providers' practice in Slovakia. There was an interest to know how significant the Q-system is for the transformation process according to the providers, and how they perceive their social services based on the new quality requirements, as well as their expectations from the Q-System and how it would influence their organisational and professional work in the future.

Many research findings could be interpreted in terms of the SRV. Comparable to the findings of other authors $[10,11$, 26] the research showed that transformation of social services based on higher quality performance requires an adoption of measures at several levels. Based on the inductively formulated responses the expectations of transformation changes at systemic (external) level, at organisational level (social service providers), as well as the level of professional performance of social services were identified. The finding that the emphasis was put particularly on the need for systemic changes in social services (such as financing, legislation, equal status of public and non-public providers, general access to social services, assessment of people's needs), with considerably lower representation of expectations of changes at the organisational level and staff expertise can be interpreted in association with numerous determining circumstances. The discussion is focused mainly on the circumstances associated with the implementation of the Q-System at national level during the past decade.

Once again, it is necessary to turn the reader's attention to specific features of the period in which the research was carried out. The year 2016 saw systemic changes in Slovakia concerning social service financing including the efforts to equalize the position of public and non-public providers of social services in the area of public support. During this relatively uncertain phase the providers started to be bound by the obligation to apply the quality standards set by law. However, the initiation of the process of external assessment has been legally postponed several times with the last deadline set for September 2019. A time gap of several years between the implementation of the quality commitments in providers' practice on the one hand, and the future external assessment by the ministry on the other hand could be the reason for internal inconsistency of some research findings. The research indicated that absenting experience of the respondents with external quality assessment of their services according to the criteria stipulated by law, as well as missing widespread education in social service quality have resulted in dual way of thinking about the quality of social services in the vast majority of respondents. In case the questions concerned the assessment of quality of their own services and whether the respondents were seeing any additional reserves or anticipating any major changes in the future, their opinions could be compared to the understanding of the quality as an intrinsic characteristic of a social service. [10] This was obvious from their statements based on the application of intuitive, subjective quality criteria resulting mainly from inter-personal relations in social services, the scope of the staff's personal involvement, their good intentions and hard work for the benefit of the users [18], with no objective validation (measurement) whether they really act in their favour [9]. In line with this approach almost all actors considered the services to be of good quality, not being aware of any major reserves; and most of them did not expect any major changes in their future work within application of the Q-system. However, over $50 \%$ of the respondents regarded the Q-System as a positive challenge in their practice in compliance with the stipulated law requirements. Such approach corresponds with the normative interpretation (quality as a norm) where standardisation and measurement options are necessary [9-10]. Due to the delay of the process of external quality assessment (since September 2019) the providers were not directly confronted with the necessity to demonstrate fulfilment of the quality standards and even lowquality practice did not result in any legal consequences. Thus, the Q-System as a potential challenge for critical reflection of organisations and their work and for adoption of necessary changes remains untapped for many providers at the national level. This is evidenced by the finding that approximately one third of the survey participants have not started the implementation of quality standards according to the law until 2016, although they were bound by the law since 2009, and 2014, respectively. Moreover, many of them regarded the process of meeting the quality standards mainly through the preparation of the necessary documentation in order to "pass the external assessment in the future ". [8]

Preferential highlighting of the need for transformation 
changes at systemic (external) level, mainly in the area of stabilisation of legislation of social services, their financing and accessibility for persons in need, is not surprising. It corresponds with well documented findings on long-term problems in social services during the past decade both in the Czech Republic and Slovakia [8]. Therefore, a systemic transformation should be in the centre of social and political attention. Nevertheless, experts should also pay attention to the fact that majority of social service providers do not recognise the need for a change in organisations and social services common practice in accordance with the requirements of the Q-System.

The need to address the transformation of social services in the equilibrium of all three levels was confirmed by further partial findings from on-going survey in 2017. There was some particular interest in the position and special role of social work in area of social services [27], as social work is considered a significant carrier of their transformation and quality - from satisfying basic human needs (warm-fed-andclean-care) towards promoting and ensuring good quality of life. [28] According to the experts participating in the research social service provision particularly long-term care social services for care dependent people with disabilities and older people, continues to be more or less caring and nursing; social work in these services is significantly over-burdened by administrative responsibilities of the providers, with neglecting developmental collaboration with service users and their families. The coordinating and mediating function of social work is also not widely appreciated among key actors (e.g. employers). [27]

These findings do not comply with the findings on high trust of the providers in the quality of their work from the 2016 research, as well as the fact that they do not perceive any major reserves for improving their work. In this context, some authors [18-29] mention the risk of weakened ability of the staff to be aware of their low quality of performance considering that they continuously work in low-quality services. This may lead to a refusal of recommendations for a change formulated by independent subjects based on the external criteria. Therefore, it is necessary to pay equal attention to all aspects of transformation of social services and quality implementation - systemic and structural, organisational as well as those focusing on professional performance and its outputs [9-10]. The problems with ensuring system parameters of social services should not overshadow the need for education, professional training, systematic methodologic support and the assessment of usual activities of the providers who are the primary quality holders in social services.

\section{Conclusions}

The article reflects the inspiring potential of the SRV used for clarification of some selected parameters in Slovak QSystem as well as for interpretation of the results of the research in which the association between the processes of transformation of social services and newly implemented Q-
System was demonstrated.

It is worthy to note that there is a significant parallel between the SRV and the Q-System with regards to social, political and professional context of the implementation of both systems. At national level, the need for transformation and deinstitutionalisation of social services originated from unsatisfactory situation in residential services for people with disabilities. Therefore, deinstitutionalisation of residential long-term care services has developed into the "normative concept" of the overall transformation of social services. [8-14] After all, the presented results of the research included predominantly the opinions of long-term care providers who accounted for the vast majority of the research sample.

The concept of normalisation, later the SVR, has been originally also developed due to the need for transformation of residential human services for people with mental disabilities. Its wider applicability in the management of services for all people with stigmatisation and marginalised groups was considered later. $[11,12,26]$ Therefore, the SRV has also a potential to inspire national research as well as practice of high quality in other areas of social services and their target groups. In particular, it is possible to think about services of crisis intervention for people in difficult life situation (e.g. loss of home, addiction, long-term ethnic based social exclusion) which has not been considered within the meaning of the valorisation theory neither in research nor in interventional practice. This may be due to the fact that satisfying the social needs of people in crisis life situation with good quality services is only gradually becoming a social and political as well as professional priority, including such oriented research in Slovakia.

\section{References}

[1] Act No. 448/2008 Coll. on social services (Zákon č. 448/2008 Z.z. o sociálnych službách). 2008. Available online: https://www.slov-lex.sk/pravnepredpisy/SK/ZZ/2008/448/20180101.

[2] Strategy on deinstitutionalisation of the social services and foster care system in Slovakia (Stratégia deinštitucionalizácie systému sociálnych služieb a náhradnej starostlivosti v Slovenskej republike). 2011. Bratislava: Ministry of Labour, Social Affairs and Family of the Slovak Republic. Available online:

https://www.employment.gov.sk/files/legislativa/dokumentyzoznamy-pod/strategia-deinstitucionalizacie-systemusocialnych-sluzieb-nahradnej-starostlivosti-1.pdf.

[3] National action plan on transition from institutional to community-based care in the social services system for years 2016-2020 (Národný akčný plán prechodu z inštitucionálnej na komunitnú starostlivost' $v$ systéme sociálnych služieb na roky 2016-2020). 2016. Bratislava: Ministry of Labour, Social Affairs and Family of the Slovak Republic. Available online: https://www.employment.gov.sk/files/rodina-soc-pomoc/socsluzby/narodny-akcny-plan-prechodu-z-institucionalnejkomunitnu-starostlivost-systeme-socialnych-sluzieb-roky2016-2020.pdf. 
[4] National priorities on improvement of social services for years 2015-2020 (Národné priority rozvoja soiálnych služieb na roky 2015-2020). 2014. Bratislava: Ministry of Labour, Social Affairs and Family of the Slovak Republic. Available online: https://www.employment.gov.sk/files/slovensky/rodinasocialna-pomoc/socialne-sluzby/np2015-2020_vd.pdf.

[5] Convention of the Rights of Persons with Disabilities. 2006. New York. Available online: https://www.ohchr.org/EN/HRBodies/CRPD/Pages/Conventio nRightsPersonsWithDisabilities.aspx.

[6] Pillinger, Jane. 2001. Quality in social public services. Luxembourg: Office for Official Publications of the European Communities.

[7] Munday, Brian. 2007. Integrated social services in Europe. Strasbourg: Council of Europe Publishing. Available online: https://www.coe.int/t/dg3/socialpolicies/socialrights/source/Pu blication_Integrated $\% 20$ social $\% 20$ services $\% 20 \mathrm{in} \% 20$ Europe $\% 20 \mathrm{E} \% \overline{20}(2)$.pdf.

[8] Repkova, Kvetoslava. 2016a. Quality in context of social services' transformation (Kvalita $v$ kontexte transformácie sociálnych služieb). Bratislava: Institute for Labour nad Family Research. Available online: https://www.ceit.sk/IVPR/images/pdf/2016/socialne_sluzby_ web.pdf.

[9] Donabedian, Avedis. 1988. The Quality of Care. How Can It Be Assessed? JAMA, 12: 1743-1748.

[10] Nies, Henk, Kai Leichsening, Roelf van der Veen, Ricardo Rodrigues, Pierre Gobet, Laura Holdsworth, Sabina Mak, Elisabet Hirsch Durrett, Marion Repetti, Michael Naiditch, Teija Hammar, Hennamari Mikolla, Harriet Finne-Soveri, Timo Hujanen, Stephanie Carretero, Laura Cordero, Maite Ferrando, Thomas Emilsson, Gunnar Ljunggren, Patrizia Di Santo, Francesca Ceruzzi and Eva Turk. 2010. Quality Management and Quality Assurance in Long Term Care. European Overview Paper. INTERLINKS: Utrecht/Vienna. Available online:: http://interlinks.euro.centre.org/sites/default/files/WP4_Overvi ew_FINAL_04_11.pdf.

[11] Thomas, Susan and Wolf Wolfensberger. 1999. An overview of Social Role Valorization. In R. J. Flynn and R. A. Lemay eds. A Quarter-Century of Normalisation and Social Role Valorisation: Evolution and Impact. Ottawa, ON: University of Ottawa Press, 125 - 159.

[12] Osburn, Joe. 2006. An overview of Social Role Valorization Theory. In The SRV Journal, 1: 4 -13.

[13] Wolfensberger, Wolf, Bengt Nirje, Simon Olshansky, Robert Perske and Philip Roos. 1972. The Principle of Normalisation in Human Services. Books: Wolfensberger Collection. Book 1.

[14] Repkova, Kvetoslava. 2017a. Social Services. Support of the meaningful ordinary life from human-rights perspective (Sociálne služby. Podpora zmysluplnej každodennosti v ludsko-právnej perspektive). Bratislava: Institute for Labour nad Family Research. Available online: https://www.ceit.sk/IVPR/images/IVPR/2017/kniha_socialne sluzby_podpora_zmysluplnej_kazdodennosti.pdf.

[15] Krupa, Slavomir ed. 2007. Transformation of the care homes facilities towards their inhabitans' social and work rehabilitation (Transformácia domovov sociálnych služieb $s$ cielom sociálnej a pracovnej integrácie ich obyvatel'ov). Bratislava: Rada pre poradenstvo v sociálnej práci. Available online: http://www.rpsp.sk/download/transformacia_dss.pdf.
[16] Cangar, Miroslav ed. 2015. Governance and management of the transition from institutional to community-based care (Riadenie a manažment prechodu z inštitucionálnej na komunitnú starostlivost'). Bratislava: Implementačná agentúra MPSVR SR. Available online:

https://www.ia.gov.sk/data/files/np_di/publikacie/Riadenie_a manazment_prechodu_z_institucionalnej_na_komunitnu_star ostlivost.pdf.

[17] Lemay, Raymond, 1995. Social Valorisation Theory and the Principle of Normalisation. In A. E. Dell Orto and R. O. Marinelli eds. Encyclopedia of Disability and Rehabilitation. New York: Simon \&Schuster Macmillan, 515-521.

[18] Lemay, Raymond. 2001. Good Intentions and Hard Work Are Not Enough: Review of: P. F. Levy, 2001. The Nut Island Effect: When Good Teams Go Wrong. SRV - VRS. In The International Social Role Valorisation Journal, 1-2: 94-97.

[19] Kendrick, Michael J. 2008. SRV as a Resource for Seeking and Shaping the Good Life. In Promoting and defending the rights and interests of people with developmental disability. Spring 2008, 7: 3-4.

[20] Armstrong, John. 2006. The Application of Social Role Valorization in Supporting People with an Intelectual Disability-An Overview. Available online:

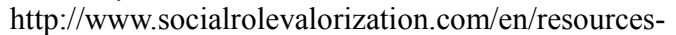
bookstore/articles

[21] Thomas, Susan and Wolf Wolfensberger. 2007. The New (3rd, 2007) Edition of PASSING. In The SRV Journal, 1: 58-62.

[22] Repkova, Kvetoslava. 2015. Implementation of the quality conditions into social services' practice-methodological backgrounds (Implementácia podmienok kvality do praxe poskytovatel'ov sociálnych služieb-metodické východiská). Bratislava: Institute for Labour nad Family Research. Available online: https://www.employment.gov.sk/files/slovensky/rodinasocialna-pomoc/socialne-sluzby/metodika-verzia-3.12komplet.pdf.

[23] Repkova, Kvetoslava. 2016b. Evaluation on quality conditions of provided social services-methodological backgrounds: draft) (Hodnotenie podmienok kvality poskytovaných sociálnych služieb-metodické východiská: návrh). (Bratislava: Institute for Labour nad Family Research. Available online: https://www.ceit.sk/IVPR/images/IVPR/vyskum/2016/Repkov a/repkova_hodnotenie_podmienok_kvality.pdf.

[24] Repkova, Kvetoslava, 2017b. Content and organisational aspects of education focused on evaluation of social services' quality-draft) (Návrh obsahových a organizačných aspektov vzdelávania pre účely hodnotenia podmienok kvality sociálnych služieb-návrh). Bratislava: Institute for Labour nad Family Research. Available online: https://www.ceit.sk/IVPR/images/IVPR/vyskum/2017/Repkov a/navrh_organizacnych_a_obsahovych_aspektov_repkova_20 17.pdf.

[25] Hlebec, Valentina and Maja Mrzel, M. 2012 Methodological problems and solutions regarding explanatory mixed methods research design. In Teoria in Praksa, 2: 245-263.

[26] Lemay, Raymond. 1999. Roles, identities, and expectations: Positive contributions to Normalisation and Social Role Valorisation. In R. J. Flynn and R. A. Lemay eds. A QuarterCentury of Normalisation and Social Role Valorisation: Evolution and Impact. Ottawa, ON: University of Ottawa Press, 219-240. 
[27] Repkova, Kvetoslava. 2018. Social work in area of social services (Sociálna práca v sociálnych službách). Bratislava: Institute for Labour nad Family Research. Available online: https://www.ceit.sk/IVPR/images/IVPR/2018/sp_v_soc_sluzb ach.pdf.

[28] Leichsenring, Kai and Anette Scoppetta. 2016. Future perspectives on social welfare policy and research-Identifying social policy issues in Europe. Vienna: GAM 2016 the
European Centre for Social Welfare Policy and Research. 2021 September, 2016.

[29] Flynn, Robert J. 1999. A comprehensive review of research conducted with the programm evaluation instruments PASS and PASSING. In R. J. Flynn and R. A. Lemay eds. $A$ Quarter-Century of Normalisation and Social Role Valorisation: Evolution and Impact. Ottawa, ON: University of Ottawa Press, 317-352. 